\title{
Some Additional Safeguards for the Newly Liberated Marketplace
}

\author{
Louis B. Schwartz†
}

Judge Breyer's impressive Article 1 identifies four "special risks" that antitrust policy will have to avert in the "newly liberated marketplace." Those risks are:

(1) The risk that an overly strict antimerger policy will be imposed on the airline industry;

(2) The risk that both rules against predatory pricing and discriminatorily high access charges will "overprotect" new competitors in the telecommunications industry by "handicapping" AT\&T, thus protecting individual competitors at the expense of competition generally;

(3) The risk that the Bell Operating Companies (BOC's), with the aid of regulators, will frustrate competition among supphers of long distance service by thwarting price cutting designed to prevent "bypassing"; and

(4) The risk that "residual monopolistic elements" or "bottlenecks"-for example, carrier-owned computerized reservation systems (CRS's)-might distort competition in favor of the integrated firm or, alternatively, thwart the economic efficiencies of integration, such as the encouragment of technological innovation by internal financing.

Judge Breyer's responses to those four problems may be summarized as follows:

(1) As to the risk of an overly strict antimerger policy in air transportation, Judge Breyer is somewhat equivocal. On the one hand, in support of a tolerant merger policy, he stresses ease of entry into new airline markets through rapid redeployment of planes and the likelihood that potential entry will restrain exploitation of the "monopoly" position in particular cities. He also suggests that the prospective "shakedown"the disappearance of nonviable firms that have been artificially protected by regulation-should be facilitated by a merger policy that both recognizes efficiencies of integration and embodies a generous "failing com-

$\dagger$ Professor of Law, University of California, Hastings College of the Law. B.S. 1932, J.D. 1935, University of Pennsylvania.

1. Breyer, Antitrust, Deregulation, and the Newly Liberated Marketplace, 75 CALIF. L. Rev. 1005 (1987). 
pany" defense. On the other hand, he calls for a "strong antimerger policy" that is "suspicious" about likely anticompetitive consequences, and he insists on achieving putative efficiency gains by the least restrictive means. Under this view, divestiture of directly competitive operations would be made a condition of approved mergers.

(2) In response to the risk that AT\&T's long distance competitors will be "overprotected" by indiscriminate laws against predatory pricing or by excessive access charges that handicap AT\&T, Judge Breyer clearly deprecates the need for regulatory or antitrust action to protect new competitors. In his view, the risk of predatory action by AT\&T is exaggerated. First of all, AT\&T is no longer a natural monopoly: Economies of scale exist with respect to only ten percent of its costs. Accordingly, its prices for particular services should be allowed to reflect "sound economic principles"; they should be allowed to decrease to incremental costs, so as to hold potential "bypassers" on the system. Furthermore, AT\&T would not engage in tactical pricing to exclude or contain competition because that would encourage reregulation or litigation based on a monopolization charge under section 2 of the Sherman Act. ${ }^{2}$

(3) Judge Breyer responds to the risk that the newly liberated BOC's will, with the aid of state regulators, mount a successful political campaign to preserve internal subsidies for local service by advocating that regulators return to "sound economic principles" when pricing local services. This position seems to mean full-cost pricing for local and rural service in order to reduce the need for a subsidy out of long distance rates. At the very least, it appears to mean that subsidies should be targeted more precisely to the needy customers-or, in other words, reduced in the aggregate.

(4) Finally, Judge Breyer proposes a combination of antitrust and regulation to avert the risk that companies with residual monopoly power in the form of "bottlenecks" will use it unfairly against competitors. On the one hand, a carrier-owned CRS might have to be divested under the antitrust laws unless this would set up perverse incentives against innovation: the "efficiency" defense again. On the other hand, anticompetitive risks resulting from the association of "bottleneck" monopolies (such as the BOC's) with other potentially competitive enterprises are arguably negligible because regulated monopolies do not have "deep pockets." Furthermore, regulators would not allow resources to be diverted from the regulated operation to affiliated competitive enterprises.

Broadly stated, the issue Judge Breyer addresses is whether the free market is an adequate safeguard of the public interest when hitherto reg-

2. 15 U.S.C. $\S 2$ (1982). 
ulated business is deregulated. As one would expect from a sophisticated long-time observer and critic of antitrust and regulation, Judge Breyer responds by breaking this general question down into its particulars. Under this approach, the question must be answered differently for each deregulated industry, not with some "average" response supposedly right for deregulating industry generally.

I emphatically agree with this approach. Yet in appraising Judge Breyer's article, it is also useful to aggregate his proposals in order to trace the general drift of his recommendations. I would say that he approves of deregulation, going further than I would in his reliance on the "free market." At the same time, he calls for relaxed application of the antitrust laws to the inarkets he considers, namely, airline transportation and telecommunications. The combination of these proposals leaves me uneasy. Regulation and antitrust have generally been regarded as complementary ways to protect public interests. To say that both systems should be simultaneously cut back is to recommend that substantial increments of discretionary power be conferred upon private management.

It seems to ine that this is precisely the wrong time in our economic and political history to call for a move in that direction. We stand at the very nadir of antitrust; it is such a dead letter that $I$ ain at a loss as to what to teach my students except that "anything goes." Only trivial and obvious horizontal price agreements provoke government action. The role of "private" complainants has been drastically curtailed, while the government intervenes on behalf of defendants. Dubious economic theories and problematic predictions of the efficiencies to be gained by restraint of trade are accepted as justifications. Accordingly, the presumption should be against any further weakening of antitrust controls.

Similarly, we must be skeptical about the wisdom of relaxing regulatory control. Putting "deregulators" in charge of regulatory agencies has undermined their effectiveness. That process has gone so far that no less a conservative than Justice Scalia called for a reversal of the traditional conservative position favoring vigorous judicial review of administrative orders. $^{3}$ As Justice Scalia saw it, the accession of ideological deregulators in the regulatory agencies called for relaxation of judicial review so as to give these sympathetic ideologues free rein to proceed with their deregulatory plans. ${ }^{4}$ Once more I say that at the nadir of regulation, liberals-and I include Judge Breyer in that honorable clan-should keep their fingers crossed about proposals to abet the Reagan administration's extremist proposals to "get the government off the backs" of powerful businesses.

3. Scalia, Regulatory Reform-The Game Has Changed, REG., Jan./Feb. 1981, at 13.

4. Id. at 14 . 
One final general observation before I proceed to examine the specifics of Judge Breyer's paper. In my opinion, it relies too much on economics as a guide to policy, and correspondingly underplays the role of law in promoting "justice." Economics is a most inexact science, which excludes from its formulae some considerations that matter very much in the real world. As I have pointed out elsewhere, "justice" must sometimes outweigh "efficiency" or putative gains in GNP. ${ }^{5}$ For example, we would not tolerate slavery even if economists could denonstrate conclusively that everybody, including the slaves, would be better off materially under a slave systein.

Turning now to the particulars of Judge Breyer's arguments, let me first record uny reservations about his measurement of concentration of power in the airline business by using an eight-firm aggregate national market share. ${ }^{6}$ His observation that this aggregate market share did not substantially increase between 1972 and 1986 (it increased from 85.7\% in 1972 to $87.4 \%$ in 1986) is not a ground for complacency. In the first place, assuming that the eight-firm aggregation is the proper base, the domination of nearly ninety percent of the market by those eight firms is statistical notice that opportunity for new competitive entry is severely limited. In the second place, given an initial market share of $85.7 \%$, it is hardly surprising that only a limited increment could be achieved. Moreover, in appraising economic power, regional dominance and the dominance of traffic between important city pairs must surely be weighed along with national market shares. Similarly, the scarcity of airport landing slots nullifies any assumption that theoretically potential entrants can readily become active coinpetitors.

What is tolerably clear is that a merger policy that "reflects" an inevitable "shakedown"- a policy that tolerates absorption or disappearance of smaller and weaker carriers-will move us toward an even higher eight-firm concentration, and probably toward a three- or four-firm oligopoly. ${ }^{7}$ Such an oligopoly would be especially unlikely to provide workable competition because the smaller carriers that remain to be acquired are likely to be discounters or otherwise "disruptive" of establishment marketing practices. Even if these potential disrupters are not acquired by the major carriers, their opportunities to mount substantial challenges against a few dominant carriers are ininimal and declining. This decline occurs not only because of limited airport slots, but also because of the inherent marketing advantages of giant carrier systems. Every extension

5. See Schwartz, "Justice" and Other Non-Economic Goals of Antitrust, 127 U. PA. L. REV. 1076 (1979); see also Schwartz, Justice, Expediency, and Beauty, 136 U. PA. L. REv. 141 (1987).

6. See Breyer, supra note 1, at 1012 n.26.

7. See Kilman, An Unexpected Result of Airline Decontrol Is Return to Monopolies, Wall. St. J., July 20, 1987, at 1 . 
of the system adds to the power of the initial carrier to route traffic preferentially over its own system. That power is augmented by major carrier ownership of "bottleneck" facilities such as CRS's. Furthermore, marketing devices-such as "frequent traveler" rebates and tie-in sales of hotel accommodations and rental cars-have relatively little appeal to travelers on airlines serving few destinations.

For these reasons, we need something more than Judge Breyer's recommendation of a "strong" antitrust pohicy qualified by generous "efficiency" and "failing company" defenses. I am especially dubious about reliance on the Department of Transportation (DOT) to define a respectable merger policy under the statutory standard of "public interest." After all, the Civil Aeronautics Board (CAB) failed that assignment under much more favorable circumstances and much closer judicial review.

Accordingly, what we need is legislative direction-regulation, if you will-that defines the public interest both for antitrust courts and the DOT. As concerns inergers, this legislation should codify Judge Breyer's preference for "the least restrictive alternative." In other words, no merger should be approved if consolidation with a different airhne would produce less anticompetitive consequences or more benefits to travelers. No such requirement now exists or is likely to develop without legislative direction. Furthermore, the legislation should inake it clear that a merger that eliminates substantial actual competition is not to be approved on the theory that potential competition will replace the lost competition. That preference for actual coinpetition over putative potential coinpetition should also be expressed, as Judge Breyer proposes, by requiring divestiture, in viable condition, of parallel routes involved in the merger, unless there is clear and convimcing evidence of overcapacity, efficiency gains, and effective competition from other lines.

With respect to claimed efficiency gains, courts and agencies should be directed to consider whether lower costs expected from a merger are likely to be passed on to the traveler. ${ }^{8}$ That is sinply another way of assuring that effective competition survives the inerger. The public interest is not served by an "efficiency" merger if the lower costs benefit investors rather than travelers. Finally, legislative policy should address the question of conglomerating utility operations. Unrelated enterprises dis-

8. That principle is embodied in the treaty establishing the European Economic Community, which exempts from EEC "antitrust" law cartels that "contribute to the improvement of the production or distribution of goods or to the promotion of technical or economic progress while reserving to users an equitable share in the profits resulting therefrom." Treaty Establishing the European Economic Community, March 25, 1957, art. 85, para. 3, 298 U.N.T.S. 11, 48 (emphasis added). 
tract airline management from their reponsibilities and blunt the force of competition within the airline industry itself.

With respect to the telecommunications industry, I am not as sanguine as Judge Breyer about the inherent safeguards against "predatory" tactics by AT\&T in the post-regulatory era. Two factors suggest that it is unrealistic to believe that the threat of a suit under section 2 of the Sherman Act will deter AT\&T from steep price cutting targeted against competitors in selected markets. First, there is the conclusive presumption of the lawfulness of prices higher than marginal costs, which Professors Areeda and Turner advocate in their influential treatise. ${ }^{9}$ Second, there is the reluctance of courts to grant relief to plaintiffs asserting predatory claims.

Several recent cases illustrate the daunting barriers to a plaintiff's succeeding in a monopoly suit based on predatory pricing.

In Telex Corp. v. International Business Machines Corp., ${ }^{10}$ IBM engaged in selective price cutting aimed at small competitors who were encroaching upon its dominant position in the peripheral equipment market. The court held that IBM was simply "engaging in the type of competition prevalent throughout the industry," 11 and accordingly held that IBM's conduct was not predatory.

In Marsann Co. v. Brammall, Inc. ${ }^{12}$ the court held that the plaintiff's case was insufficient despite expert testimony that the defendant's price to United States Steel - a crucial customer of the plaintiff-covered only approximately two-thirds of the average variable cost of providing such service. The court concluded that the plaintiff was required to prove that the defendant had cut prices below the average variable cost of serving the particular customer. ${ }^{13}$

Finally, in Matsushita Electric Industrial Co. v. Zenith Radio Corp. ${ }^{14}$ the Supreme Court sustained a summary judgment for the defendants on the ground that predatory pricing claims were inherently implausible under the "Chicago School" model of antitrust analysis. ${ }^{15}$ According to that model, it does not make economic sense for a dominant firm to accept present losses in exchange for potential future

9. See 3 P. AReEda \& D. TuRner, ANTITRUST LAw If 711d (1978 \& Supp. 1986); L. Schwartz, J. FlynN \& H. First, Free Enterprise and Economic Organization: ANTITRUST 130-35 (6th ed. 1983).

10. 510 F.2d 894 (10th Cir.), cert. dismissed, 423 U.S. 802 (1975).

11. Id. at 928. See also Sullivan, Monopolization: Corporate Strategy, the IBM Cases, and the Transformation of the Law, 60 TEX. L. REV. 587 (1982).

12. 788 F.2d 611 (9th Cir. 1986).

13. Id. at 615 .

14. 106 S. Ct. 1348 (1986).

15. For a discussion of the Chicago School of antitrust analysis, see Posner, The Chicago School of Antitrust Analysis, 127 U. PA. L. REV. 925 (1979), reprinted in ANTITRUST LAW AND EcoNomics 17 (O. Williamson ed. 1980). 
supracompetitive prices that may not be realized because entry barriers are low. Accordingly, the Court concluded that:

[P]redatory pricing schemes required conspirators to suffer losses in order eventually to realize their illegal gains; moreover, the gains depend on a host of uncertainties, making such schemes more likely to fail than succeed. These economic realities tend to make predatory pricing conspiracies self-deterring: unlike most other conduct that violates the antitrust laws, failed predatory pricing schemes are costly to the conspirators. $^{16}$

Unfortunately, that remarkable willingness to accept as fact the theoretical postulates of one school of economics-thereby taking the case from the jury-affords scant grounds for optimism regarding the utility of section 2 of the Sherman Act as a brake on predatory pricing.

Judge Breyer's solution for the perceived risk that "bottleneck" and other "residual" monopolistic elements will survive deregulation leans toward regnlation. For example, he believes that there are both benefits and dangers in the integration of air carriers with CRS's, and that a regulatory agency is better equipped than a court to balance those benefits and dangers.

I am disposed to accept these premises, but with such intense skepticism about both the reliability of forecasts of economic benefits and the feasibility and impartiality of "balancing" that I would insist on clear legislative guidelines that impose heavy burdens of proof on the protagonist of an anticompetitive integration. Sucl legislative guidelines could come from Congress or, more likely, from close judicial review of regulatory decisions in this area. For example, the guidelines could be patterned on those incorporated in the Bank Merger Act of $1966 .{ }^{17}$ That Act requires an agency or reviewing court to disapprove a proposed merger unless the anticompetitive effects are "clearly outweiglied" by the "convenience and needs of the community to be served." 18

More significant than merger controls is the question of whether to allow dominant carriers to finance de novo entry into potential "bottleneck" operations such as CRS's. Such enterprises are desirable not merely because they promote efficiency, as Judge Breyer notes, but also because they improve service to users. However, as the service expands to include listings of rival carriers, the potential for discrimination against them increases. Equal access to the bottleneck becomes critical to the survival of the rival carriers, and some formula for their sliaring in the benefits of an essential technological innovation must be devised.

16. Matsushita, $106 \mathrm{~S} . \mathrm{Ct}$. at 1360.

17. Act of Feb. 21, 1966, Pub. L. 89-356, $\S 1,80$ Stat. 7, (codified as amended at 12 U.S.C. $\S 1828(1982))$.

18. 12 U.S.C. $\S 1828(c)(5)(1982)$. 
Means must be found for converting what was a desirable integration in an infant industry to an independent or cooperative facility that will capture the full benefits of scale economies for customers without discriminating against trade rivals. ${ }^{19}$

In sum, my answer to Professor Handler's question is that the "free market" is not an adequate safeguard of public interest in newly deregulated industries so long as antitrust laws remain at the present nadir of interpretation and enforcement. Among the additional safeguards required, whether by way of tightened antitrust standards or by regulatory controls subject to strict judicial scrutiny, are the following:

(1) Assurance that "efficiencies" claimed for proposed mergers or other competition-restricting maneuvers will be passed through to consumers;

(2) Assurance that the legality of predatory pricing will be judged not merely with reference to coverage of variable costs, but also with reference to exclusionary purpose and effect;

(3) Assurance, especially if concentration in the deregulated industry is high and skewed, of fair access not only to "bottleneck" facilities but also to effective interconnection with dominant through-route or long distance carriers. This principle should be applicable not only to airline deregulation but also to rail, pipeline, and telecommunication deregulation;

(4) Assurance that mergers resulting in the elimination of actual competition shall not be approved merely because of theoretical potential entry;

(5) Antitrust immunity for "state action" should, in the context of deregulation, be reexamined and restricted. For example, where the industry that is deregulated is one that engages in much "self-regulation," the lawfulness of anticompetitive behavior should be tested by a rule of reason that takes into account the state's diluted control, rather than by an immunity rule that bars public inquiry under the antitrust laws; ${ }^{20}$ and

(6) In general, where a tribunal is called upon to balance

19. Cf. Otter Tail Power Co. v. United States, 410 U.S. 366 (1973) (mandating "wheeling" of power purchased from competitors); United States v. Terminal R.R. Ass'n, 224 U.S. 383 (1912) (mandating equal access to crucial bridge connection); Alabama Power Co. v. Nuclear Regulatory Comm'n, 692 F.2d 1362 (11th Cir. 1982) (mandating shared ownership in nuclear power plants), cert. denied, 464 U.S. 816 (1983); United States v. Eastman Kodak Co., 1954 Trade Cas. (CCH) If 67,920 (W.D.N.Y. 1954) (consent decree requiring separate charges for sale and processing of color film).

20. Cf. Southern Motor Carriers Rate Conference v. United States, 105 S. Ct. 1721 (1985) (motor carriers may collaborate in price-fixing with minimal state supervision); Patrick v. Burget, 800 F.2d 1498 (9th Cir. 1986) (uphoiding lawfulness of state supervised peer review as basis for excluding physician from hospital staff); Ohio AFL-CIO v. Insurance Rating Bd., 451 F.2d 1178 (6th Cir. 1971) (permitting collective ratesetting by insurance companies despite allegations of 
maintenance of competition against achievement of specified public interest goals, the protagonist should be required to prove that the latter "clearly outweighs" the former and cannot be achieved by less restrictive means. 
